We don't sufficiently
elevate the art
and science of
communication in
our strategies nor
do we value or
even understand
communication skills
and invest anything
like what we should
in ensuring that our
communicators are well
equipped with them

We don't sufficiently elevate the art and science of communication in our strategies nor do we value or even understand communication skils and invest anything like what we should communicators are well equipped with them and these things should be said somewhere, probably often. Where better than a 'how-to' book on campaigning?

It is careless in places too, eg Page 16, where it cites the cost of employee misunderstandings (through bad communications) in the United Kingdom and the United States as $£ 31$ million (US\$62 million). No, not even if the dollars were Australian or Canadian, as even with them it's been a while since we got two for one. For US dollars, it would be more like $\$ 48$ million. But the point is well made. Poor communications badly campaigned costs shedloads, in any currency.

And this is nit-picking. Most of this book is plain nuts and bolts, no high ground is taken. Except for its constant reiteration of the basic observation that, for our causes, we need and deserve to be heard. And we can be, if only we do it properly.

The important thing, which this book articulates well, is that most of the organizations we work with do information by the binlorryload, at vast expense, but often border on useless at communication. They get stuff out, but don't get it through. Paradoxically, we don't sufficiently elevate the art and science of communication in our strategies nor do we value or even understand communication skills and invest anything like what we should in ensuring that our communicators are well equipped with them.

Campaign it!: Achieving success through communication gives you a very good starting point to putting this paradox right. I recommend that you buy several copies, distribute them among your most talented folks then tell them you'll be asking questions soon and that jobs will hinge on it. But keep one copy back for yourself, so that you'll know at least as much about the campaign approach to communication as they do.

You won't regret it. And your job will be safe.

Ken Burnett Hon F IDM

\section{Digital wars: Apple, Google, Microsoft and the battle for the internet}

Charles Arthur

Kogan Page, 2012; £14.99; 272pp.

ISBN: 978-0749464134 (Paperback)

Journal of Direct, Data and Digital Marketing Practice (2012) 14, 84-86. doi:10.1057/dddmp.2012.21

Charles Arthur has been the technology editor for The Guardian since 2005, and his 'Digital Wars' is a highly readable account of the evolution since 1990 of that part of the technology industry that focuses on consumer products involving search, digital music, smartphones and tablets. This evolution is given dramatic context by being framed within an account of a series of battles between the protagonists competing to control access by consumers to digital information and services. 
Arthur believes that the essential character of these competing organizations can only be properly understood in terms of the technologies and technical challenges that were current when their founders were in their early 20s. By the same token, an account of this sort will provide generationally different insights. Younger, more digitally attuned readers will benefit from the contextual information contained in the accounts of the earlier battles, while many older readers will find the book invaluable for its account of products and technologies with which they may not have personal first-hand experience.

Any account of the evolution of the industry that structures itself around the battles between its main protagonists cannot help but pose more general questions relating to successful business strategy. One of the strengths of this book is that while it is not explicit in arguing the merits of particular strategies, the evidence it provides of productive and unproductive management strategies within this particular business sector has clear relevance to many other sectors.

Those who have worked more extensively than Arthur in such sectors will therefore find much of interest to reflect on, not just how these particular battles were won or lost.

A key issue throughout the book is the advantages and disadvantages of vertical integration, Apple's success being attributed to its deliberate decision to control all aspects of user experience of its products. Only through vertical integration, it is argued, can a company avoid the pressure on margins that results from commodification, a key indication of which appears when consumers are encouraged, whether by retailers of reviewers, to evaluate brands or models based on the number of ticks on a comparison card.

A second recurring issue is the advantage Apple gained through relentless prioritization of user experience over considerations of functionality and price. It is only through an enjoyable, even tactile, user experience that a product or brand can achieve an emotional response from its user and hence enjoy the loyalty and iconic status that Apple, perhaps alone among technology brands, has managed to achieve. The concept behind the Apple shop exemplifies this perfectly.

Arthur is clearly of the view that Microsoft's inability to successfully challenge Apple or Google with me-too products is rooted in management style, Jobs' interference in product design being the result of his deep technical and user understanding, and the interference of Microsoft management under Ballmer, being mostly unproductive.

In such a ruthlessly competitive environment Arthur makes much of the strategy, successfully employed by both Google and Apple, of keeping innovation 'under the radar' for as long as possible, in the case of Apple firing any supplier whose staff disclosed confidential information about its intentions. A powerful case is made for the proposition that it is difficult for an organization that dominated one phase of technological evolution to control the next one. This is because each phase undermines the monetized value of products developed during the previous one, which incumbents necessarily have an interest in protecting. 
The only respect in which I would take issue with this book is that it gives insufficient recognition, at least explicitly, to the differences in the core skills that are often referred to as the DNA of each protagonist.

Microsoft's success is founded in its ability to manage the accurate and detailed compilation of an extensive set of technical standards that facilitate interoperability and technical integration between different applications, mostly for the benefit of those with complex tasks to undertake. Google's success is based on a much deeper understanding than Microsoft of the value of data and how data can be linked and remodelled to maximize predictive decisioning. Apple by contrast reads from this account as an organization in the image of a person who harnessed technological adaptability with a restless search for the most satisfying user experience, most often for a person who sought pleasure from applying an elegant sophistication to tasks that were immediate, not necessary essential and often leisure based.

Richard Webber Hon F IDM

\section{Changing the world is the only fit work for a grown man: An eyewitness account of the life and times of Howard Luck Gossage - 'Sixties America's most ... influential and irreverent advertising genius}

Steve Harrison

Adworld Press, 2012; £11.99, 208pp., ISBN-10: 0957151500; ISBN-13: 978-0957151505 (Paperback)

Journal of Direct, Data and Digital Marketing Practice (2012) 14, 86-87. doi:10.1057/dddmp.2012.16

I have just read the most compelling book that I have encountered for many years. Writing a 600-word review is not easy because 2,000 would barely do it justice.

The book is 'Changing the world is the only fit work for a grown man' by Steve Harrison.

\section{A true 'one-off'}

It's the story of a true 'one-off' in the advertising business. The word genius is bandied about too easily, but in the case of Howard Luck Gossage it really is the only word that fits.

This is a man who invented social networking, interactive advertising, pay per view media, media independents, PR events and more, all 30 or more years before they happened on a broad front.

He was not always popular with his contemporaries, advocating as he did that the commission system of payment for advertising agencies was wrong because 'bad ads earn more than highly efficient ones', that is, they had to be run more often to achieve the same result.

He resigned one of his major accounts because although the client was happy with the advertising Gossage wasn't — clearly a man of huge integrity. 